Минский государственный лингвистический университет

\title{
ЯЗЫКОВЫЕ СРЕДСТВА АКТУАЛИЗАЦИИ ЭКСПРЕССИВНОСТИ В ПРОФЕССИОНАЛЬНОМ ДИСКУРСЕ ЖУРНАЛИСТОВ (НА МАТЕРИАЛЕ АНГЛО- И РУССКОЯЗЫЧНЫХ ПЕРСОНАЛЬНЫХ ЖАНРОВ)
}

В статье рассматриваются языковые средства актуализаџии категории экспрессивности в персональных жанрах американского и белорусского медийного дискурса. Категория экспрессивности является оной из наиболее значимых для адекватного понимания и интерпретации современных медиа в контексте технологической конвергенции, ускорения процессов обмена информацией, сущчественных преобразований жанровой системы, а также возрастающей субъективности.

С целью выявления тенденциий языковой репрезентации упомянутой выше категории в американском и белорусском медиадискурсе тексты в жанрах «мнение», «блог» и «колонка» были подвергнуты лингвостилистическому, контекстуальному и сравнительному анализу. В результате обобщения результатов количественных подсчетов, полученных 6 ходе лингвостилистического анализа, было установлено, что персональные жанры, функционирующие в американском дискурсе, характеризуются примерно одинаковой экспрессивностью на лексическом и синтаксическом уровнях, в то время как персональные жанры медийного дискурса Беларуси демонстрируют более высокую степень экспрессивности на синтаксическом уровне, что свидетельствует о склонности белорусских авторов прибегать к менее явным проявлениям экспрессивности в сравнении с американскими коллегами.

При более иироком спектре средств актуализации экспрессивности на уровне синтаксиса в жанрах на обоих языках, выявленные приемы выполняют две основные прагматические функциии в дискурсе: функцию акцентууачии и функциюю диалогизации. Инвентарь лексико-стилистических приемов 
является вдвое менее разнообразныл, однако, реализует при этом в исследуемых жанрах в два раза больше прагматических функций (объяснительная, обобщуающая, композиционная функичя, а также функции сокращуения дистанцฺии, укрепления доверия и экономии языковых средств).

Ключевые слова: дискурсивная категория, медийный дискурс, персональные жанрыл, экспрессивность, стилистический прием, прагматическая функция, сравнительный анализ

UDC 81'42

https://doi.org/10.25076/vpl.41.05

P.P. Glazko

Minsk State Linguistic University

\section{EXPRESSIVE LANGUAGE MEANS IN PROFESSIONAL DISCOURSE OF JOURNALISTS (AS USED IN PERSONAL GENRES IN ENGLISH AND RUSSIAN)}

The article deals with the language means of actualization of the category of expressiveness in personal genres of American and Belarusian media discourse. The category of expressiveness is one of the key categories for adequate understanding and interpretation of modern media and effective cross cultural communication in the context of technological convergence, increased information sharing, significant changes in genre system and accretive subjectivity.

To elucidate the trends in representation of the above-mentioned category in American and Belarusian media discourse recently published texts of different authorship belonging to different personal genres of modern media, to wit, opinion, blog, and column were subjected to linguo-stylistic, contextual and comparative analyses. As a result, it has been found out that while personal genres of American discourse are equally expressive at lexical and syntactical levels, personal genres in Belarusian discourse demonstrate a greater degree of expressiveness from syntactical point of view, which indicates the preference of Belarussian authors towards implicit means of expressiveness as compared with their American colleagues.

It has been noted that syntactical devices perform the dialogical 
function and that of accentuation, whereas lexical devices perform explanatory, distance shortening, compositional, generalizing functions as well as those of enhanced credibility and economy of language.

Keywords: discourse category, media discourse, personal genres, expressiveness, stylistic device, pragmatic function, comparative analysis

\section{Introduction}

Despite the fact that the category of expressiveness (or expressivity) has been tackled in a plethora of scientific papers and monographs from multifarious perspectives and points of view, it is still in the focus of linguists' attention as a topical issue due to a number of reasons. First and foremost, expressiveness is an inherent feature of human communication which permeates practically all spheres of human activity and interaction bringing to light the attitude of the author of discourse and other communicants to the events, opinions, and actions reflected in the discourse. Apart from that, expressiveness proves to be a multifaceted complex phenomenon which can be studied from different angles, at different language levels, and with the help of various research methods: philosophy of language, semantics, pragmatics, stylistics, text linguistics, etc. In addition, rendering expressive inventory of one language with the means of another language in social practices, for example, in translation or interpreting, can turn out to be quite a predicament, thus pointing out the necessity for comparative linguistic studies of the category in question, the results of which could contribute to a better understanding of national character specificity and human nature in general as well as to more efficient cross-cultural communication in particular. All of the abovementioned aspects are deemed to be absolutely indispensable nowadays in the context of the shift towards the anthropological research paradigm.

The aim of the given paper is to elucidate the culture specific features of rendering expressiveness in personal genres of Belarusian and American media space, thus bringing together and contrasting lexical and syntactical language means of expressiveness used in genres under analysis in the English (that of the USA) and Russian (that of Belarus) languages. 


\section{The role of expressiveness in media discourse}

It could hardly be denied that these days modern media are gaining currency as a source of information, entertainment and knowledge about the world (Ivchenkov, 2019; Lassan, 2020; Vishnyakova \& Polyakova, 2017). It is not surprising that modern media are frequently deemed to be the classical literature of the 21st century (Annenkova, 2008). The language of media has become high profile due to a number of reasons: the integration of information and communication technologies (also known as technological convergence), the increase in information sharing, a more important role of dialogization as a basic feature of modern media, a substantial change in genre system alongside a greater level of subjectivity (Elliot, 2000; Chicherina, 2007). A lot of recent studies corroborate the idea that "we are witnessing a shift from mass media logic to social media logic, and specifically that one of the ways in which this logic manifests is in the use of more subjective language" (Welbers \& Opgenhaffen, 2019, p.45). Iu. S. Volkova, V.A. Mishlanov, V.A. Salimovskii argue that today one does not seek tenable explanation or upending of assumptions, but rather covets an opportunity for self-expression (Volkova, Mishlanov \& Salimovskii, 2019). Within the framework of our research we accept the all encompassing character of expressiveness in modern media, but alongside this assumption we would like to conjecture and further validate that the means of its actualization in discourse will be different in different cultures, hence the novelty of the study.

\section{Materials and methods}

For this purpose, we selected 50 recently published texts ( 25 texts in each language) of different authorship belonging to different personal genres of modern media, to wit, opinion, blog, and column from the corresponding sections. The choice of genres was motivated by the fact that they are typically associated with personal discourse and therefore are likely to be highly saturated with expressive means in comparison with institutionalized genres, while also being quite popular with readers taking into account the trends of media content consumption discussed above.

The procedure of the analysis included five stages. At stage 1 the selected texts were subjected to linguo-stylistic analysis, in the result of which a list of lexical and syntactical stylistic devices used in the texts 
under analysis was made up. In those cases when an expressive syntactical structure contained a lexical stylistic device (for instance, a rhetorical question containing a metaphor), both the syntactical structure and the lexical stylistic device were considered to be two different phenomena and they were further counted as such since they perform absolutely different functions, namely, those of emphasis and creating imagery. During stage 2 a quantitative analysis was carried out which made it possible to identify the most and the least frequently used expressive means in the genres under scrutiny. At stage 3 with the help of contextual analysis the functions of the afore-mentioned devices were specified, thus elucidating their pragmatic potential and shedding light on the reasons for their greater or lesser productivity in discourse. Stage 4 involved calculations of the degree of expressiveness of the genres under consideration at lexical and syntactical levels with index method. Stage 5 was based on a comparative study of the findings with the aim to point out the common and culture specific features of actualization of the category of expressiveness in personal genres of American and Belarusian media discourse.

\section{Results and discussion}

The result of linguo-stylistic analysis and quantitative analyses are presented in Table 1 below.

\begin{tabular}{|l|l|l||l|l|l|}
\hline $\begin{array}{l}\text { Lexical } \\
\text { Stylistic } \\
\text { Devices }\end{array}$ & $\begin{array}{l}\text { America } \\
\text { n Media } \\
\text { Discour } \\
\text { se }\end{array}$ & $\begin{array}{l}\text { Belarusi } \\
\text { an } \\
\text { Media } \\
\text { Discour } \\
\text { se }\end{array}$ & $\begin{array}{l}\text { Syntactical } \\
\text { Stylistic } \\
\text { Devices }\end{array}$ & $\begin{array}{l}\text { America } \\
\text { n Media } \\
\text { Discours } \\
\text { e }\end{array}$ & $\begin{array}{l}\text { Belarusia } \\
\text { n Media } \\
\text { Discours } \\
\text { e }\end{array}$ \\
\hline & $\begin{array}{l}122 \\
(54,2 \%)\end{array}$ & $\begin{array}{l}82 \\
(61,2 \%)\end{array}$ & enumeration & $\begin{array}{l}66 \\
(31,4 \%)\end{array}$ & $\begin{array}{l}44 \\
(22,8 \%)\end{array}$ \\
\cline { 4 - 6 } epithet & \multirow{2}{*}{$\begin{array}{l}59 \\
(26,2 \%)\end{array}$} & $\begin{array}{l}24 \\
(17,9 \%)\end{array}$ & insertions & $\begin{array}{l}46 \\
(22 \%)\end{array}$ & $\begin{array}{l}21 \\
(10,9 \%)\end{array}$ \\
\cline { 4 - 6 } & repetition & $\begin{array}{l}23 \\
(11 \%)\end{array}$ & $\begin{array}{l}6 \\
(3,1 \%)\end{array}$ \\
\hline $\begin{array}{l}\text { set } \\
\text { expressio } \\
\text { ns }\end{array}$ & $\begin{array}{l}32 \\
(14,2 \%)\end{array}$ & $\begin{array}{l}21 \\
(15,7 \%)\end{array}$ & parallion-in- & $\begin{array}{l}22 \\
(10,5 \%)\end{array}$ & $\begin{array}{l}13 \\
(6,7 \%)\end{array}$ \\
\cline { 4 - 6 } & & & $\begin{array}{l}17 \\
(8,1 \%)\end{array}$ & $\begin{array}{l}28 \\
(14,5 \%)\end{array}$ \\
\hline
\end{tabular}




\begin{tabular}{|l|l|l|l|l|l|}
\hline & & & question & $(6,1 \%)$ & $(19,1 \%)$ \\
\hline \multirow{3}{*}{$\begin{array}{l}\text { metonym } \\
\text { y }\end{array}$} & $\begin{array}{l}12 \\
(5,4 \%)\end{array}$ & $\begin{array}{l}7 \\
(5,2 \%)\end{array}$ & detachment & $\begin{array}{l}12 \\
(5,7 \%)\end{array}$ & $\begin{array}{l}23 \\
(12 \%)\end{array}$ \\
\cline { 5 - 6 } & & antithesis & $\begin{array}{l}11 \\
(5,2 \%)\end{array}$ & $\begin{array}{l}21 \\
(10,9 \%)\end{array}$ \\
\hline Total & $\begin{array}{l}225 \\
(100 \%)\end{array}$ & $\begin{array}{l}134 \\
(100 \%)\end{array}$ & Total & $\begin{array}{l}210 \\
(100 \%)\end{array}$ & $\begin{array}{r}193 \\
(100 \%)\end{array}$ \\
\hline
\end{tabular}

Table 1. Expressive language means in personal genres of American and Belarusian media discourse

As we can see, the spectrum of syntactical means in both the languages is wider and encompasses 8 devices, whereas the lexical group comprises only 4 devices. At the same time from a quantitative point of view in American discourse these two groups of expressive means are virtually equal (225 vs 210 units), while Belarusian authors tend to resort to syntactical means more often (193 vs 127 units).

If we look into the lexical group of expressive means, we will see that the American and Belarusian authors demonstrate similar preferences in terms of use of lexical stylistic means as the numbers decrease gradually and proportionally to the total. The metaphor turns out to have the leading position due to its great explanatory potential. Owing to the associative similarity between two or more heterogeneous objects or phenomena bound by the metaphor it becomes much easier for the author to communicate their message to the reader. The metaphor saves the author the trouble of breaking down a new complex idea for the reader by rerouting it through the sphere of common knowledge. For example: I'd assumed that my desire to visit the same place every day was fairly idiosyncratic, so I was surprised by how enthusiastically people embraced this idea. As we can see, in this sentence taken from the text «Is There a Place You'd Like to Visit Every Day?» Gretchen Rubin uses a verb metaphor embrace while pondering over her idea about visiting the same place for a year on a daily basis and the possibility of this experience to affect your perception of this place. What the author means is that this idea was accepted eagerly by her readers, but in lieu of this or any other expression with a similar meaning she opts for a one-word metaphor. On the one hand it is more economical, on the other hand it allows the 
author to add an implicit emotive component to what she was meaning to say, insofar as to embrace stands for 'to put your arms around someone and hold them in a loving or friendly way'. In other words, not only did her readers accept her idea, but they did it ina very supportive and friendly way.

In the text «Почему макияж на лице парня - это круто?» German Klimenko is trying to address the issue of gender prejeduces, namely, the issue of how appropriate it is today for a male to wear make-up in Belarus. The author starts off by casting his mind back and recollecting his school years when he got hurt while playing outside and became self-conscious enough about the bruise on his face to try make-up for the first time in his life: Причиной моего первого макияжа стал снежок, угодивший в мой левый глаз. Помню, что это был снаряд размером с бильярдный шар: от удара я кувыркнулся на землю, уставился в декабрьское небо и заревел. Через десять минут я сидел на кухне, прижимая к лииу замороженную сосиску, она должна была унять боль. В принципе, сосиска со своей задачей справилась - боль ушла, а вот фиолетовая слива на моем глазу осталась. Similarly to Gretchen Rubin, German Klimenko prefers a one-word metaphor over a descriptive phrase for the associative power of metaphor saves him the trouble of dwelling on the shape, colour, and other attributes of his trauma additionally. It helps to present this information is a compact way, but simultaneously it enables the reader to visualise the properties of the bruise, and by doing so to understand the author's motives better.

The epithet is a runner-up stylistic device in terms of its popularity with American and Belarusian authors. Partially it is due to the fact the metaphor and the epithet are based on the same mechanism of stylistic interplay of meanings. The difference between them lies in their distribution peculiarities, with the metaphor being more syntactically independent and the epithet being bound by its attributive finction. The texts both in English and Russian are characterised by the use of simple epithets possessing different degree of originality. Some of the epithets are indeed quite hackneyed and are boardering on cliches (tough feedback, bustling hub, breathtaking destination; светлое будущее, иветущее здоровье), while others are more creative and less predictable, and therefore are more emotionally charged (bottomless brunch, inexhaustible place; отрезвляюший опьт). Unlike texts in 
Russian, English texts often contain phrase epithets - epithets that are constituted by word combinations or clauses. The grammatical properties of the English language make it possible to use phrases with their own predication as attributes, thus adding up to the overall expressiveness and reflecting the personal perception of certain phenomena.

For instance, in one of the texts in English on a popular practice to write New Year resolutions the author resorts to the following phrase epithet: Often, we try to do something the "best" way, or the "right" way, or try to force ourselves to adopt a system that works well for someone else. But there's no magical, one-size-fits-all-solution for good habits or happiness. The epithet one-size-fit-all is eye-catching as it is owing to its graphical formatting which additionally enhances the association between lifestyle tips and items of clothing pointing out that all people might have more or less similar measurements or at least they can be sorted out into groups in terms of sizes whereas when it comes to human mind it is virtually impossible to do the same.

It should be noted that on rare occasions phrase epithets can occur in Belarusian texts too. They function according to the same priciples, but because of structural characteristics of the Russian language they seldom look the same as phrase epithets in English, to wit, they mostly occur in postposition to the main word: Идти по жизни с принципом «моя хата с краю» очень легко: просто нужно внушать себе, что бездомные животные не пропадут, им обязательно помогут другие люди. Неважно, что «другие люди» пройдут мимо котов точно с такими же мыслями: фраза «тут я ничего поделать не могу" нивелирует самые зубастые угрызения совести. As we can see from these examples, apart from their position in relation to the main word, Russian phrase epithets are not hyphenated, but are put in the inverted commas, which also prompts that they are associated not with other objects or phenomena, but rather with those people (or their collective image) who were the sources of these words.

The use of set expression in American and Belarusian discourse contributes to its general credibility and to shortening the distance between the author and the audience by making the author's language similar to that we use in our every day life (to dig deeper, to wreak havoc, to flatter the curve; заводить шарманку, праведный гнев, опускать руки). Having said that, it should be mentioned, that 
American authors unlike their Belarusian counterparts tend to resort to experiments with set expressions by adding words or omitting words. For example, in the text «Reflectin on 2020 in NYC» Tracy Kaler prolongs the set expression to see a light at the end of the tunnel by adding the demonstrative pronoun that and the adjectives long and dark to it: There is a light at the end of that long, dark tunnel, and with a vaccine here, recovery is in our future. By doing so the author endows the statement with a note of her personal evaluation adapting it to the context of the epidemic situation in the USA. At the same time various acts of set expression decomposition testify to the flexibility of the language of modern media making it seem both colloquial and literary and enabling it to rip the benefits of both.

The metonymy has proved to be the least popular lexical stylistic device in the discourse of American and Belarusian journalists. In all the cases when the metonymy occurs it presents groups of people as a unity and therefore performs the generalizing function: As NYC went on pause for three months, only essential businesses remained open; Государство не особо заинтересовано в защите бездомных питомиев. In the former example the metonymic use of a noun stands for the inhabitants of New York City, in the latter - for the government representatives. But in both the cases the authors strive to present the corresponding people as a homogeneous group.

In contrast to lexical expressive means which come across as quite uniform in American and Belarusian discourse, expressive means of syntactical level show a different tendency in their use. As we can observe in the table the texts selected from American media contain far more lexical expressive means than the texts from Belarusian media discourse. At syntactical level though it can be seen that American and Belarusian texts have their peaks and lows.

The most favoured device at syntactical level in both media cultures turns out to be enumeration. As an expressive device the enumeration binds together a number of heterogeneous objects, notions, or phenomena which, as a rule, belong to absolutely different classes of things, hence the expressive potential of the device: The day you arrived, you held fast to big dreams and the belief that this is a place where anything is possible. Now, you follow a daily routine that is far from exciting. Once fascinating - the energy, people, and sounds have become annoyances; Но ведь совсем не страшно признать, 
что чаще всего виноват ты сам. Недопридумал, недоделал, не раскрутил, устал по пути и потерял энтузиазм. The extensive use of enumeration in the texts under analysis can be motivated by the authors' intention to get through to the reader. The authors suggest various alternatives as if they were angling for the readers' tastes, interests, and experiences or for a better explanation of the subject matter.

Apart from simple enumeration, there are also cases of gradation in which every consecutive item is more emotionally charged than the previous one or presents the development of a logical sequence: For this challenge, I needed a place I could easily visit, day after day. A large place, a beautiful place, and an inexhaustible place; Поставить уже точку во всей этой истории взаимоотношений, понять и простить тех, кто когда-то обидел, и осознать, что даже самая вредная училка не желает тебе зла. Apparently, unlike simple enumeration, gradation is geared to put across the author's feelings and attitude in more detail. Thus we can infer that simple enumeration is reader-oriented, whereas gradation is author-oriented.

In American media discourse enumeration can perform a compositional function, i.e. authors may utilize the device at different stages of their narrative, which creates an echo effect all through the text binding all the compositional blocks together. For instance, in the text «7 Quick, Easy Gestures I Use to Show Love to My Sweetheart» dedicated to Valentine's Day the author starts off by saying that for her social holidays serve as trackers of self-development: Some people dismiss Valentine's Day as a consumerist holiday pushed by marketers, but I like seeing milestones throughout the year; they remind me to think about changes I might undertake to make myself happier, healthier, more productive, or more creative. In this opening gambit an author-oriented gradation can be observed, the effect of which is intensified through the use of comparative forms of the adjectives happy, healthy, productive, creative. Later in the text the author writes about the ways she can show signs of caring to her husband. The text is structured as a list the subtitles of which form enumeration: 1. Snap attention. 2. Help with chores. 3. Send fun photos and updates etc. And then each subtitle is followed by short explanations of what is meant by it and contains its own cases of enumeration: 1. Snap to attention. I find it hard to drag my attention away from my book, my phone, the 
newspaper, a TV show...but when Jamie talks to me, I remind myself to pay attention, and to show that I'm paying attention by putting down my book, muting the TV, or whatever.

Apart from enumeration, American and Belarusian media discourse have no other intersection points in terms of preferences of expressive syntactical means use. The next most popular syntactical stylistic device in American personal genres is insertions, whereas in Belarusian genres it is the fifth most popular device after rhetorical questions, parallelism and detachment.

Journalists resort to insertions in order to establish a dialogue with their readers which is why in this type of discourse insertions are usually expressed by side remarks, additions, addresses or questions to the readers (often of ironic nature): For instance, when we travel (remember when people traveled?), he always wants to unpack right away; While it may seem like a good way to relax, the glare from those screens actually stimulates light receptors in our skin, which signals the brain to stay awake (the same way natural sunlight helps us wake up); And unbelievably, some level of normalcy (what's that?), as an end to this cataclysmic year and a virus that took too many too soon, is in view; Подчеркну, что создатели «Сна Гоголя» в своих заявлениях не высказывали обид на некультурных горожан, а просто приглашали прийти и купить книгу (до конца января магазин продолжает работать); Обижаться тоже. Лучше радоваться победам и новым открытиям, которых - оглянитесь вокруг и вспомните, каким был Минск 8-10 лет назад - все равно больше.

The same function of establishing a dialogue is performed by rhetorical questions (second most popular device in Belarusian texts and sixth most popular - in American ones): Be honest - do you have a habit of watching $T V$, reading online articles, or scrolling through your phone in order to wind down before bedtime? И вот сидел я и думал: где же наша доблестная милиция? It should be noted that rhetorical question frequently occur in the strong positions within a text - in the title and at the very end. For example, the text of Greg Giagrande is entitled «Am I wrong in expecting a thank-you note after a job interview?». A text from Masha Kirilchyk's column is entitle as «Чmo не так с бодипозитивом?». Later on in this very text we can see a series of rhetorical questions which serve the same compositional 
function as enumeration in the text 47 Quick, Easy Gestures I Use to Show Love to My Sweetheart», namely, that of organizing the author's narrative: Но если мы признаем красивым тело, которое отличается от общего «стандарта» красоты, то почему это тело подгоняется под требования $\kappa$ худому? Почему ретушируются складки, целлюлит, растяжки? Это мощный эволюиионный механизм - люди стремятся стать лучше и получают образец для подражания. Почему это должно считаться чем-то плохии?

One more powerful tool of establishing a dialogue between the author and the reader is question-in-the-narrative. Unlike rhetorical questions which give the reader food for thought, hold their attention, streamline their thoughts, questions-in-the-narrative also suggest possible answers to these questions. For example, in his text «How to Be Happy: 8 Ways to Be Happier Today» Joshua Becker while contemplating various definitions of happiness uses the following question-in-the-narrative: Both definitions are understood to be correct and speak of different realities. But are they really that different? I don't think so. The same device can be observed in the text by Alexey Gorbash dedicated to the situation in one of the most buzzed-about places of Minsk - Oktyabrskaya street: $\mathrm{Mbl}$ аборигены Октябрьской последней пятилетки - потратили долгое время, чтобы возвести ее в культ: «Вот, у нас есть такая крутая улииа, давай пойдем туда!» Так и получилось: туда стали ходить все. Класс? Да, но нет: «все» - это слишком. Interestingly, in media discourse questions-in-the-narrative are nearly always built according to the same scenario: first the author gives a descriptive introduction into the subject matter, then asks a question which is followed by a negative answer: When will New York be back to what it was pre-pandemic? I'm not sure; Does that mean every day is a great day with no trials, temptations, or downturns? Certainly not; Довольно безобидный сиенарий? Да, но нет: все быстро выходит из-под контроля; Громкая колоночка или мощная аудиосистема в машине - это какой-то новый способ показать, что ты - класс? Нет, братан, получается, все немножечко наоборот. Such an approach allows the author to spice up their narrative by introducing two contrasting opinions within one structure.

The rest of the syntactical devices - repetition, parallelism, 
detachment, and antithesis - can be grouped according to the function they perform in discourse, to wit, accentuation. Repetition presupposes reoccurrence of words or word combinations in close proximity in discourse. Repetition can be unstructured in which case it can be traced in any part of the sentence emphasizing the most significant words in a sentence: New York will always be great. It's a city that exemplifies greatness. Yes, even in its darkest hour, New York is the greatest city in the world; Никто не заберет у меня право любить свое тело каким угодно [...]. Но никто не дает мне право и даже возможность навязать другому человеку, [...].Уважать человека - значит оставить за ним право субъектности. Право самому решить, что ему нужно, а что нет. Я оставляю за собой право делать со своим телом все, что хочу, как и оставляю такое же право за другим человеком. In these examples both authors endeavour to accentuate those words which communicate their message. In the first case it is the greatness of New York, in the other - the author's recognition of other people's right to treat their bodies as they find fit.

Alternatively, repetitions can be structured according to an anaphoric or epiphoric pattern and occur at the beginning or at the end of a clause: But when we change, a relationship changes, and when we change, the atmosphere of our household changes; Bce mom ж⿻上 потертый пол, те же зеленые темные коридоры, то же растение в деревянном горике у кабинета директора. As we can see in the examples the writers are trying to focus our attention on the relevant attributes of the situations described - mutability and immutability accordingly.

Syntactical parallelism enables the author to make their text more rhythmical and wrap up in this rhythm a multitude of possible alternatives, suggest numerous solutions, reveal the multi-faceted character of life. For instance, in his text «Find a Rational Minimalism that Works For You» Joshua Becker promotes the philosophy of minimalism. To be more persuasive the author utilizes the device of parallelism to prove that this type of lifestyle can be suitable for everyone: After all, you live a different life than everyone else. You may have a large family, small family, or no family. You may live on a farm, in a house, or in a studio apartment. You may collect antiques, stamps, or bottle caps. You may love music, movies, sports, or books. You may cherish old photographs, family 
heirlooms, or romantic letters from a lover. Similarly, Anton Kashlikov while dwelling on the reasons for some places in Minsk to be more popular than others resorts to parallelism to exemplify a typical way of passing the buck: Соблазн свалить все на плечи какой-то не такой публики - слишком велик и так многим подходит. На кониерт не купили билеты - виноваты глупье зрители, которым подавай попсу. В кафе не пришли посетители ax, вы не поняли нашу концепциюю. Мы делали наш подкаст, но его никто не слушал-аудитория не доросла.

In contrast to parallelism, which is hard to spot in the text visually, detachment is quite prominent in this respect. Not only that, detachment endows written discourse with a note colloquial speech: But I think what has left me saddest is the part of the city that's missing - the lifeblood of New York and its beating heart. Broadway. The Ballet. The Opera. Classical music. Jazz. Standup comedy; И пройти в любую минскую тусовку можно только через секретный обряд инициации. Назвать три признака фейковых лабутенов, к примеру. Или процитировать Акудовича. Смотря куда хочешь nonacmb. Unlike enumeration, which makes its items look like equally important endless alternatives, detachment puts every single item in the limelight.

Antithesis binds together sets of opposite notions within one syntactical structure which gives writers an opportunity to tap into its potential of bring out controversies, discrepancies, or paradoxes of life and therefore to stimulate readers' interest: Transit ridership is down, but subway crime is ир; Но в мире, где красивы все, - не красив никто. В мире, где все гении, - никто не гений. В мире, где все равны, всегда будет тот, кто ровнее. В соревнованиях, где все победители, - никто не победитель. As a rule, all antitheses add a philosophical note to any text since they elucidate causativeconsecutive dialectic interdependencies in life.

Based on the results of quantitative analysis, the index of general $\mathrm{E}(\mathrm{g})$, lexical E(1) and syntactical E(s) expressiveness for American and Belarusian personal media genres has been worked out using the formula $\mathrm{E}=\mathrm{S} / \mathrm{T}$, where $\mathrm{E}$ is the expressiveness index, $\mathrm{S}$ - the total number of lexical and / or syntactical devices, and $\mathrm{T}$ - the number of texts analysed. The results are summarized in Table 2. 


\begin{tabular}{|c|c|c|c|}
\hline $\begin{array}{r}\text { Index of } \\
\text { Expressiveness }\end{array}$ & $\mathrm{E}(\mathrm{g})$ & $\mathrm{E}(\mathrm{l})$ & $\mathrm{E}(\mathrm{s})$ \\
\hline $\begin{array}{l}\text { Type of } \\
\text { Discourse }\end{array}$ & & & \\
\hline American & 17.4 & 9 & 8.4 \\
\hline Belarusian & 13.08 & 5.36 & 7.72 \\
\hline
\end{tabular}

Table 2. Index of expressiveness in American and Belarusian personal genres

It has been found out that the index of general expressiveness is higher in American media genres (17.4) in comparison to Belarusian ones. Lexical expressiveness of texts in English (9) is higher than that of Belarusian ones (5.36). The same can be said about syntactical expressiveness too -8.4 vs 7.72 accordingly. While lexical and syntactical expressiveness of texts in English is relatively balanced ( 9 and 8.4), we can see obvious predominance of syntactical expressive means over lexical ones in the texts by Belarusian authors (5.36 and 7.72).

\section{Conclusion}

The results of the analysis allow us to make the following conclusions. Being an inherent feature of modern media, the category of expressiveness is actualized in American and Belarusian media discourse not only at lexical, but also at syntactical level. The texts in English turn out to be more saturated with expressive means in comparison to the texts in Russian. While personal genres of American discourse are equally expressive at lexical and syntactical levels (although the number of lexical means is marginally higher), personal genres in Belarusian discourse demonstrate an obvious predominance of syntactical means over lexical ones. This might be a ground for us to put forward a conjecture about a more explicit expressive character of personal media genres in American discourse and a more implicit approach towards formulation one's opinion in personal genres of Belarusian media.

At the same time, the results being discussed can't but draw our attention to the fact that the spectrum of syntactical stylistic means of 
expressiveness is much wider than that of lexical stylistic means ( 8 designations vs 4 accordingly). Interestingly, it has been noted that 8 syntactical devices perform 2 pragmatic functions in discourse (the dialogical function and that of accentuation), whereas 4 lexical devices perform 6 different pragmatic functions in the same genres (explanatory, distance shortening, compositional, generalizing functions as well as those of enhanced credibility and economy of language).

It seems to be rather promising to persevere in this line of research and bring to light the language means of representation of other categories in personal discourse of American and Belarusian media.

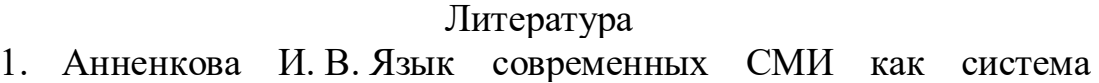
интерпретации в контексте русской культуры (попытка риторического осмысления) // Язык современной публицистики: сб. статей. М.: Флинта; Наука, 2008. С. 99-114.

2. Волкова Ю. С., Мишланов В. А., Салимовский В. А. Аргументативная речь в массмедийном интерактивном общении // Медиалингвистика. 2019. №6(2). С. 164179. DOI: $10.21638 /$ spbu22.2019.202

3. Ивченков В. И. Новые модели коммуникации и стилистические приоритеты современного медиадискурса // Медиалингвистика. 2019. № 6 (1). С. 135-144. DOI: $10.21638 /$ spbu22.2019.110

4. Лассан Э. Р. О некоторых тенденциях в грамматике текста на электронных новостных порталах: «растворение» субъекта // Медиалингвистика. 2020. № 7 (4). С. 396 - 408. DOI: $10.21638 /$ spbu22.2020.402

5. Чичерина Н. В. Типология медиатекстов как основа формирования медиаграмотности // Известия РГПУ им. А. И. Герцена. 2007. Т. 9. № 47. С. 159 - 166.

6. Elliott D. Essential shared values and $21^{\text {st }}$ century journalism: the handbook of mass media ethics. New York: Routledge, 2000.

7. Vishnyakova O. D., Polyakova N. V. Linguistic and functional cognitive peculiarities of media language as the basis of interpretations in the communicative sphere // Training, Language 
and Culture. 2017. №1(2). Pp. 86-101. Doi: 10.29366/2017tlc.1.2.6

8. Welbers K., Opgenhaffen M. Presenting News on Social Media // Digital Journalism. 2018. № 7(1). Pp.45-62. DOI: $10.1080 / 21670811.2018 .1493939$

References

Annenkova, I. V. (2008). Yazyk sovremennyh SMI kak sistema interpretatsii $v$ kontkste russkoj kultury [The Language of modern mass media as interpretation system in the context of Russian culture]. In Yazyk sovremennoj publitsistiki (pp. 99-114). Moscow.

Chicherina, N. V. (2007). Tipologija mediateksta kak osnova formirovanija mediagramotnosti [Media text typology as a basis of media literacy formation]. Izvestia RGPU im. A. I. Gertsena, 9(47), 159-166.

Elliott, D. (2000). Essential shared values and $21^{\text {st }}$ century journalism: the handbook of mass media ethics. New York: Routledge.

Ivchenkov, V. I. (2019). Novye modeli kommunikatsii i stilisticheskie prioritety sovremennogo mediadiskursa [New Models of Communication and Stylistic Priorities of Contemporary Media Discourse]. Media Linguistics, 6(1), 135144. DOI: $10.21638 /$ spbu22.2019.110

Welbers, K., \& Opgenhaffen, M. (2019). Presenting News on Social Media. Digital Journalism, 7(1), 45-62. DOI: 10.1080/21670811.2018.1493939

Lassan, E. R. (2020). O nekotoryh tendenciyah v grammatike teksta na ehlektronnyh novostnyh portalah rastvorenie subekta [On some tendencies in the grammar of news text on electronic news portals: The dissolution of the subject]. Media Linguistics, 7 (4), 396-408. DOI: $10.21638 / \mathrm{spbu} 22.2020 .402$

Vishnyakova, O. D., \& Polyakova, N. V. (2017). Linguistic and functional cognitive peculiarities of media language as the basis of interpretations in the communicative sphere. Training, Language and Culture, 1(2), 86-101. Doi: 10.29366/2017tlc.1.2.6

Volkova, Iu.S., Mishlanov, V.A., \& Salimovskii, V.A. (2019). Argumentativnaya rech $\mathrm{v}$ massmedijnom interaktivnom obshchenii [Argumentative speech in mass media interactive 
communication]. Media Linguistics, $6 \quad$ (2), 164-179. DOI: $10.21638 /$ spbu22.2019.202

У ДК 8137

https://doi.org/10.25076/vpl.41.06

Е.П. Мурашова

Московский государственный лингвистический университет

\section{ДИНАМИКА СЕМАНТИЧЕСКИХ ИЗМЕНЕНИЙ ТЕРМИНА «НОСТАЛЬГИЯ» КАК КЛЮЧЕВОГО КОМПОНЕНТА PETPO}

Статья посвящена изучению динамики семантических изменений, которым подвергся термин «ностальгия» со времени своего появления в XVII в. до настоящего времени. На фоне проиессов глобализаџии и информатизаџии общества большую популярность приобретает феномен ретро, имеющий иелью вызвать у реципиента ностальгию. Лингвистического обоснования целесообразности того или иного определения ностальгии при разработке проблем ретро в гуманитарных науках, в том числе в лингвистике, до настоящего времени не представлено. Цель данной статьи - описать изменения, которые были привнесены в семантику термина «ностальгия» с XVII по XXI вв. с учетом его денотативного и коннотативного значений. Материалом исследования служат тексты Британского, Американского и Русского национальных корпусов, опубликованные в период с 1800 по 2020 гг. В результате анализа материала выявлен существенный сдвиг в значении термина «ностальгия». Во-первых, с течением времени было утрачено исходное медицинское значение «тоска по родине как заболевание», и термин стал обозначать тоску не только по месту, но и по времени. Во-вторых, в 1980-х г2. термин «ностальгия» утерял отрицательную коннотацию и приобрел положительную окраску. B-третьих, в XXI в. ввиду постмодернистской тенденции $к$ номадизму, предполагающей сглаживание культурных грании, значение термина «ностальгия» было размыто, что в некоторых случаях преобразовало его в широкозначное существительное. В рамках статьи предлагается 